\title{
Flipping the Writing Classroom: Focusing on the Pedagogical Benefits and EFL Learners' Perceptions
}

\author{
Maha Bader Alghasab ${ }^{1}$ \\ ${ }^{1}$ English Language Dept., College of Basic Education, The Public Authority For Applied Education and Training \\ (PAAET), Kuwait
}

Correspondence: Maha Bader Alghasab, English Language Dept., College of Basic Education, The Public Authority For Applied Education and Training (PAAET), Kuwait

Received: February 24, 2020

Accepted: March 16, 2020

Online Published: March 18, 2020

doi: $10.5539 /$ elt.v13n4p28

URL: https://doi.org/10.5539/elt.v13n4p28

\begin{abstract}
The flipped classroom is an instructional strategy that encourages students to undertake prior preparation for lessons, in particular through the use of online materials provided by their teachers. Empirical studies of the language classroom have supported the effectiveness of this strategy for language development. However, only a limited number of studies have been undertaken in this field, particularly when it comes to the Arab region. This current study therefore explores the application of the flipped classroom with Kuwaiti student teachers of the English language attending the College of Basic Education in Kuwait. It aims to explore the pedagogical benefits for the development of writing skills, in particular the experiences and perceptions of learners. The study took place over a period of thirteen weeks during the first semester of the 2019 academic year. The participants were thirty EFL student teachers taking a course in advanced writing. The data collection employed both a questionnaire and semi-structures interviews. The findings revealed that students have a generally positive attitude towards the process of flipping the writing classroom. The results from the questionnaire suggested that the flipped classroom provides: (1) a more effective learning environment; (2) flexible paced learning capable of improving students' writing strategies (in particular when planning and writing a thesis and topics sentences); and (3) enhancement of students' motivation and interaction. However, the additional findings from the semi-structure interviews revealed a number of sociocultural and contextual factors with a potentially negative influence on learners' interaction. This study consequently argues that this classroom transformation demands more than a simple addition of technology and out-of-classroom videos and activities, requiring a change in the way students view education.
\end{abstract}

Keywords: flipped classroom, technology, writing skills, students' perceptions, EFL learners

\section{Introduction}

Flipped learning is a pedagogical approach inversing the way instruction is presented (FLN, 2014). It is "a learning strategy that offers preparatory or foundational content outside of the classroom and uses class time for active learning" (Cobb \& Steele, 2014, p. 2). This approach enables students to access lectures and classroom content by means of pre-recorded videos prepared (or selected) by their teachers. This enables the time in the classroom to be devoted to answering questions raised by students, as well as engaging in a group discussion and addressing any issues that may remain unclear. Teachers can flip their classrooms by requesting their students to read a given text in their own time, along with watching supplemental videos and problem solving. This facilitates the integration of online materials with face-to-face instruction. The flipped classroom includes an element of blended learning, giving students additional time for learning before, during and following lessons (Bergmann \& Sam, 2012). This strategy consists of four main pillars: (1) a flexible environment; (2) a learning culture; (3) intentional content; and (4) the presence of a professional educator (FLN, 2014).

1. 'Flexible environment' refers to the provision of a variety of learning modes (i.e. physically rearranging the classroom and supportive group work) and a flexible approach to students' learning.

2. 'Learning culture' refers to the process of transferring instruction from being teacher-centred to student-centred, i.e. students are encouraged to take an active role in exploring, discussing and co-constructing knowledge through engagement in classroom activities. 
3. 'Intentional content' facilitates classroom activities (i.e. teachers decide which material their students need to explore).

4. The presence of a professional educator highlights the role of the teacher in providing feedback, as well as monitoring and assessing group work.

These four pillars complement each other, and it is therefore vital for teachers to consider these pillars of the flipped classroom. In Second/Foreign Language (SL/FL) classroom, the application of flipped classroom has become a favourable practice sine it aligns with language learning theories (Haghighi, Jafarigohar, Khoshsima \& Vahdany, 2018).

\section{Flipped Classroom and Sociocultural Theory}

The premise of flipped learning is based on the sociocultural perspective (Vygotsky, 1978) of Second Language Acquisition (SLA). Learning forms a social activity, in which all higher mental activities are mediated (Lantolf, 2000a). Mediation refers to "the process through which humans deploy culturally constructed artefacts, concepts and activities to regulate (i.e. gain voluntary control over and transform) the material world, or their own and each other's social mental activity" (Lantolf \& Thorne, 2006, p. 79). Lantolf (2000b) noted that mediation can take place between a teacher and his/her students, or amongst the students themselves (i.e. social mediation), including artefact mediation (e.g. language or technology). Language takes the form of a collaborative conversation with social mediators (teachers/peers) to develop the cognition of other students (Mercer, 1996; Swain, 2000). Mediation is thus essential from a SCT perspective. However, Vygotsky (1978) argued that development can only take place if mediation occurs in the Zone of Proximal Development (ZPD). This is the difference between the individual capabilities of a child (i.e. his/her current ability) and their performance with assistance from mediators, including parents, teachers, peers and cultural tools (i.e. his/her potential ability).

The flipped classroom provides a social environment in which the teacher is able to provide the necessary cultural tools to assist students achieve a high level of proficiency (Yang, Yin \& Wang, 2018). This due to the capacity for most factual knowledge to be acquired by means of self-paced learning. Teachers' uploaded materials (both text and videos) are all mediational tools capable of regulating an individual's cognitive activity, including his/her writing skills. In addition, the devotion of classroom time to discussion and answering students' questions is compatible with the sociocultural perspective that learning takes place during social interaction supported by scaffolding instruction (Lantolf, 2011).

\subsection{Flipping the Language Classroom}

In language classrooms, findings supported the benefits of this approach for language learning, identifying the flipped classroom as enhancing students' language skills (i.e. speaking), allowing the majority of time in the classroom to be devoted to: (1) meaningful interaction (Abdulla et al., 2019; Yang, Yin and Wang., 2018); (2) the development of pragmatic competence (Haghighi, et al., 2018); (3) the acquisition of vocabulary and grammar (Kang, 2015); and (4) the development of writing skills (Ekmekci, 2017; Engin, 2014). The improvement of language skills was attributed to the pedagogical features of flipped classrooms, i.e. students being provided with the relevant instructional materials prior to attending the lesson, along with the use of active learning in the classroom, with students encouraged to think critically while engaging in problem solving and decision-making.

Empirical studies investigating the perceptions of learners and teachers concerning this strategy have reported mixed findings, identifying both benefits and challenges. Hung (2015) undertook pioneering research into the adoption of the flipped classroom in the context of EFL, reporting that the use of WebQuest provided an active learning environment, one that increased the involvement and participation of students. In addition, Turan and Akdag-Cimen (2019) noted that the flipped classroom promoted two keys aspects of learners' autonomy and student-centred learning, both of which enhanced learner engagement (Amiryousefi, 2017). Kim (2017) and Yang et al. (2018) found that lower level thinking (i.e. understanding and remembering) can be enhanced by self-paced materials, in contrast to higher level cognitive processes (i.e. application, analysis, evaluation and creation) which are capable of being developed in class. These findings accord with those of Engin (2014), i.e. that students are more likely to become expert and develop higher order cognitive skills. A number of further researchers have noted an increase in the motivation, engagement and satisfaction of students, in response to prior preparation helping to reduce anxiety (Abdulla et al., 2019; Haghnighi et al., 2018; Huynh \& Nguyen, 2019). Haghnighi et al. (2018) further specified that the flipped classroom awards students additional opportunities to engage in meaningful interaction, particularly in comparison to the conventional classroom, in which $90 \%$ of the time is taken up by the delivery of a lecture, with only $10 \%$ being dedicated to the communicative use of speech acts. 
Despite these positive findings, it should be recognised that initial resistance may arise in response to any abrupt changes in the way learners are taught (Homma, 2015). Webb, Doman and Pusey (2014) reported that both intermediate Chinese University EFL students and teachers developed gradual positive attitudes towards the flipped classroom, following the initial implementation failing to meet students' expectation of the role of their teachers. The authors found that $88.7 \%$ of EFL university students preferred teachers to give in-class instruction rather than by means of videos. A number of other researchers have found that only $10 \%$ of students viewed the videos prior to the lesson, with only those who considered them useful watching to the end (Watanabe, 2014).

Turan and Akdag-Cimen (2019) undertook a systematic review of the literature, identifying the main challenges as: (1) the additional workload incurred for both learners and teachers; (2) issues concerning technology and the Internet; and (3) anxiety related to writing. Students expressed a number of concerns. Firstly, the large amount of practice required, due to their belief that they were expected to undertake a greater amount of work than for conventional lessons (Haghighi et al., 2018). Secondly, the lack of clarity of the videos when not prepared by a professional teacher and the style of peer presentation (Engin, 2014). Thirdly, students felt the teacher-fronted classroom was more conducive to learning (Webb et al., 2014). Fourthly, they wished to be given more online instruction, as they enjoyed the online information as a means of supplementing classroom materials and reinforcing some of the concepts being taught (Haghighi et al. 2018).

Webb et al. (2014) found that teachers tended to hold similarly negative attitudes, which then gradually improved. They noted that some teachers expressed scepticism about implementing the flipped classroom, citing issues in ensuring problematic students were interested in out of class materials, which also needed to be explored again in the classroom. However, the attitudes of both teachers and students were found to increase in positivity, particularly once they recognised that a flipped classroom simultaneously supports students' learning while saving time for teachers.

Thus, the findings from the literature demonstrate the potential effectiveness of the flipped classroom. However, Turan and Akdag-Cimen (2019) identified a lack of research into both the advantages and challenges, particularly in the context of EFL. Furthermore, there remains a scarcity of research into this subject in Arab countries; including very limited quantitative studies examining the impact of flipped the classroom on writing development (Abdulla et al., 2019; Al-Harbi \& Alshumaimeri, 2016). The majority of studies examine these issues through a quantitative perspective, employing an experimental/quasi-experimental design (i.e. using a pre-post-test). This current study therefore explores the application of flipped classroom in Kuwait, with the aim of examining the benefits and challenges of the flipped classroom, in particular in relation to writing.

\section{Methodology}

\subsection{Aims and Research Questions}

This study explores the pedagogical benefits of the flipped classroom for improving the writing skills of EFL learners attending a College of Basic Education in Kuwait. The research aimed to elicit learners' perceptions of the flipped learning experience in the advanced writing classroom. It employed a questionnaire and interviews to answer the following research questions:

1. What is the perception of learners towards the flipped classroom experience?

2. What are the main pedagogical benefits of a flipped learning strategy when applying it to the writing classroom?

\subsection{Methods}

This research was undertaken in a College of Basic Education (CBE) in Kuwait, one of the colleges of the government's higher education organization for the Public Authority for Applied Education and Training (PAAET). The participants consisted of EFL student teachers from the English language department. Students attending CBE train to become teachers in various different disciplines (i.e. English), following the successful completion of a four-year undergraduate programme. Students majoring in the English language are required to attend a number of basic courses, which include: (1) writing (i.e. basic and advanced); (2) conversation; and (3) reading. Successful completion leads to further courses in applied linguistics, linguistics and literature.

The participants of the current study consisted of thirty EFL Kuwaiti female students, ranging in age between eighteen and twenty-four, taking a compulsory course called 'Advanced Writing'. All the participants majored in the English language at the College of Basic Education, and had commenced learning English at primary school. They were required to attend an advanced writing course of one and a half hour, twice a week. This focused on improving their writing skills in a number of different genres, including: (1) narration; (2) exposition; (3) cause and effect; (4) process analysis; and (5) descriptive writing. The course took place during the first semester, i.e. 


\section{from September to December 2019.}

The students received an orientation of the flipped classroom approach and the use of Edmodo (i.e. a free learning management tool that merges classroom content and facilitates online students/teachers interaction in a safe and private online platform), being given the class code for joining an Edmodo group. They were required to undertake activities both outside and inside the classroom, as well as watching YouTube Videos, visiting recommended websites and studying reading materials prior to attending class. All of the online materials were accessible in the Edmodo group, thus giving the students greater freedom to watch videos and read materials at any time of the day, both before and following lessons.

The main feature of the flipped classroom consists of the instruction taking place outside the classroom, followed by related activities during the lesson. The content was designed by the researcher, who was teaching students on the course. Three days before a class, the students were asked to either watch a short lecture video delivered by their own teacher (between six and seven minutes) or a YouTube Video. This was followed by recommended exercises, worksheets and online quizzes and reading materials related to the assigned lesson (see Table 1). The students were encouraged to post comments on the videos and engage in discussions with their classmates. They were also asked to keep a study log (to be handed over to the teacher before each class) confirming they had watched the videos and read the materials. The study log included various questions designed to measure the students' engagement with the materials outside the classroom. The lesson itself was divided into three main sections, each consisting of half an hour, as follows: (1) discussion; (2) writing; and (3) peer feedback. The discussion section required students to discuss the macro structure of their essay, based on the information acquired from the videos. This was followed by being asked to work individually to write the required paragraphs. Once they had completed this task, they exchanged their drafts with each other for the process of peer review.

Table 1. The process of flipping the advanced-writing classroom

\begin{tabular}{|c|c|c|c|c|c|c|c|}
\hline Activities & $\begin{array}{c}\text { Weel \&2 } \\
\text { What is a } \\
\text { paragraph? }\end{array}$ & $\begin{array}{c}\text { Week } 3 \\
\text { Grammar and } \\
\text { peer review } \\
\text { process }\end{array}$ & $\begin{array}{c}\text { Week } 4 \\
\text { Essays and thesis } \\
\text { statement }\end{array}$ & $\begin{array}{c}\text { Week } 5 \& 6 \\
\text { Descriptive } \\
\text { writing }\end{array}$ & $\begin{array}{c}\text { Week } 7 \& 8 \\
\text { Comparison } \\
\text { and contrast }\end{array}$ & $\begin{array}{c}\text { Week } 9 \& 10 \\
\text { Cause and effect } \\
\text { essay }\end{array}$ & $\begin{array}{c}\text { Week } 11 \& 12 \\
\text { Exposition }\end{array}$ \\
\hline $\begin{array}{l}\text { Out -of -class } \\
\text { activities on } \\
\text { Edmodo }\end{array}$ & $\begin{array}{c}\text { Watching a video } \\
\text { recorded by course } \\
\text { teacher. } \\
\text { Reading hand-out } 1 \\
\text { on topic sentences } \\
\text { and planning } \\
\text { strategies. } \\
\text { Visit websites to } \\
\text { find out the topic } \\
\text { sentence for each } \\
\text { paragraph. .https:// } \\
\text { www.eslprintables. } \\
\underline{\text { com }}\end{array}$ & $\begin{array}{c}\text { Watching } \\
\text { YouTube videos } \\
\text { to revise } \\
\text { different } \\
\text { tenses/peer } \\
\text { review process. } \\
\text { Reading } \\
\text { Hand-out on } \\
\text { run-on sentences } \\
\text { and punctuation. } \\
\text { Grammar drills } \\
\text { on } \\
\text { https://www.kha } \\
\text { nacademy.org }\end{array}$ & $\begin{array}{c}\text { Watching YouTube } \\
\text { videos to } \\
\text { differentiate between } \\
\text { paragraph and essay / } \\
\text { topic sentences and } \\
\text { thesis statement. } \\
\text { Using Edmodo } \\
\text { comments write } \\
\text { essay title, thesis } \\
\text { statement and topic } \\
\text { sentences followed } \\
\text { by sharing them with } \\
\text { instructor and } \\
\text { classmates on } \\
\text { timelines. }\end{array}$ & $\begin{array}{c}\text { Watching } \\
\text { YouTube video } \\
\text { for descriptive } \\
\text { writing. } \\
\text { Websites and } \\
\text { online exercise } \\
\text { on simile and } \\
\text { metaphors. } \\
\underline{\text { https://www.gra }} \\
\underline{\text { mmarly.com/blo }} \\
\text { g/whats-the-diffe } \\
\underline{\text { rence-between-a- }} \\
\underline{\text { simile-and-a-met }} \\
\underline{\text { aphor/ }}\end{array}$ & $\begin{array}{c}\text { Read } \\
\text { worksheet for } \\
\text { the essay on } \\
\text { comparison } \\
\text { and contrast } \\
\text { designed by } \\
\text { the teacher. } \\
\text { Visit the } \\
\text { following } \\
\text { website } \\
\text { https://saylordo } \\
\text { torg.github.io/t } \\
\text { ext_writing-for } \\
\text {-success/s14-0 } \\
\text { 7-comparison- } \\
\text { and-contrast.ht } \\
\text { ml } \\
\text { In groups, } \\
\text { students } \\
\text { choose two } \\
\text { aspects to } \\
\text { compare and } \\
\text { contrast. } \\
\text { Create their } \\
\text { plan using } \\
\text { clustering } \\
\text { technique. } \\
\text { Write their } \\
\text { essay. }\end{array}$ & $\begin{array}{c}\text { Watching } \\
\text { YouTube video } \\
\text { on case and } \\
\text { effect essay. } \\
\text { https://www.cour } \\
\text { sera.org/lecture/g } \\
\text { etting-started-wit } \\
\underline{\text { h-essay-writing/c }} \\
\text { ause-effect-video } \\
\text {-lecture-QpT51 } \\
\text { Read worksheet } \\
\text { provided by } \\
\text { teacher } \\
\text { Plan and write } \\
\text { their essays } \\
\text { In pair: students } \\
\text { engage in } \\
\text { peer-review. }\end{array}$ & $\begin{array}{c}\text { Watching a } \\
\text { video recorded } \\
\text { by the course } \\
\text { teacher. } \\
\text { Practice } \\
\text { expository } \\
\text { writing by } \\
\text { planning and } \\
\text { writing essays } \\
\text { at home. }\end{array}$ \\
\hline
\end{tabular}




\subsection{Data Collection Instruments}

Two instruments were used to explore learners' perceptions of the implementation of a flipped classroom for their advanced writing lessons. In Week 12, an adapted version of a questionnaire designed by Haghighi et al. (2018) was distributed to the students, containing twenty questions on a 5 point Likert scale. The researcher adapted the questionnaire by deleting some unrelated statements and adding items 2,3,4,5 and 7 to match the focus of the instructional programme focusing on flipping the writing classroom (Questionnaire Appendix A). Prior to being distributed, the questionnaire was revised by four English language experts. The final version was subsequently piloted with ten randomly selected students. All of the correlation coefficient between the items and their themes were significant at a level of 0.01 , indicating a suitable inner consistency. The reliability measurement of the questionnaire suggested an acceptable Cronbach's Alpha coefficient of 0.896 (see Appendix B).

Semi-structured interviews of ten minutes were also conducted with all students (see Appendix C). These consisted of open-ended questions related to the themes of the questionnaire. All interviews were recorded using the recording programme in iPhone 10.

\subsection{Data Analysis}

The data collected by means of the questionnaire was subsequently analysed using the statistical software SPSS. Descriptive statistics were used to illustrate the mean scores of the participants in relation to each item of the questionnaire. The data from the semi-structured interviews was transcribed verbatim, followed by the application of thematic analysis, in order to elucidate the effectiveness of the flipped classroom.

\section{Findings}

The main findings suggest that the Kuwaiti EFL students in this study held a positive attitude towards the flipped classroom, perceiving it as an effective strategy for improving their written work due to: (1) providing an improved learning environment; (2) motivation for writing; (3) flexibility of time; (4) enhancement of learners' participation and interaction; and (5) improvement of their writing skills. Table 2 sets out the positive attitudes of the participants towards the flipped classroom. The mean value for the dimensions ranged from 3.94 to 4.46 , with the total questionnaire mean being 4.19 , thus indicating a high average value.

Table 2. Descriptive statistics of learners' perceptions of the flipped classroom

\begin{tabular}{cccccc}
\hline Themes & Means & SD & Min & Max & Rank \\
\hline Learning environment & 4.35 & .442 & 3 & 5 & 2 \\
Writing skills & 3.94 & .585 & 3 & 5 & 5 \\
Flexible paced learning & 4.20 & .555 & 3 & 5 & 3 \\
Interaction & 4.03 & .686 & 3 & 5 & 4 \\
Motivation & 4.46 & .557 & 3 & 5 & 1 \\
Total questionnaire & 4.19 & .482 & 3 & 5 & \\
\hline
\end{tabular}

Table 2 reveals the main pedagogical benefits of the flipped classroom as: (1) the enhancement of learners' motivation when it came to their written work; (2) the creation of a more conducive learning environment; (3) the development of flexibly paced learning; (4) the promotion of learners' interaction; and (5) the improvement of writing skills. These results are discussed in further detail below.

\subsection{Motivation}

One of the issues related to students' written work concerns their low levels of motivation. This is due to second language learners tending to view such tasks as tedious. However, in the current study, the use of the flipped classroom enhanced the motivation of the participants, resulting in the highest mean score being observed for promoting learners' motivation. The questionnaire revealed that the Kuwaiti students found a flipped classroom enhanced their motivation, with Q18 confirming that the majority $(90 \%)$ consequently experienced increased motivation towards their written work, while $10 \%$ were neutral. In response to Q 19, 93.2\% agreed or strongly agreed that the format of the flipped classroom helped them to take the subject seriously.

"I felt motivated because I knew what the teacher would tell us in class and, umm, you know when it comes to writing it is boring, but when I knew what we were going to write about I prepared things ahead, which helped me to feel relaxed." (Anfal)

"I loved the flipped classroom, because it made me prepare before class (sic). I also learned a lot from this 
writing class, so my writing skills now are better than before. Watching a video always motivates me. That's what really helped us and made me love writing".

This reveals that their prior preparation acted to enhance students' motivation. A total of $90 \%$ agreed and strongly agreed with the statement in Q20 that the flipped classroom reduces tension and fear because of the prior preparation. Their tension levels were also reduced, allowing them to practice various aspects of the lesson in advance. For example, Malak stated:

"For me, the writing class is very stressful...you know, when it comes to writing, you need to not only focus but, ammm, I mean you need to think quickly, which is very challenging and sometimes frustrating, because you cannot express all your ideas in short time... the flipped classroom allowed me to be prepared ahead and this was really helpful. I felt relieved".

Shahad, Isra and Ola all felt excited about the prospect of their writing tasks. They declared that their feelings towards writing had been transformed by the flipped classroom, enabling them to start enjoy writing and taking it as an interactive and interesting task.

"Before this, I found writing really boring. I loved the flipped classroom, because it made me prepare before the class. I felt so happy, because I learned a lot from the videos and other materials and this made me love writing." (Shahad)

"I have really profited from the flipped classroom, and I now enjoy every activity. It has changed my perspective toward writing, ahm, it made writing so interactive and interesting... actually, it changed my way of writing. (Isra)

"I hated writing and always found these were the classes I least enjoyed, because writing is not a single activity, but you may need to go through many steps to write one page... it is exhausting. But I have now changed my opinion and writing has become one of my favourite tasks". (Ola)

\subsection{Better Learning Environment}

The students' responses to the questionnaire questions suggest that the flipped classroom offers an improved environment for practicing writing skills (Q1, Q6, Q13, Q14 and Q16). The results demonstrated that the majority agreed or strongly agreed (i.e. 76.7\%) that their learning was improved by the flipped classroom in comparison to their usual lessons, while $10 \%$ disagreed and a similar percentage remained neutral. $80.5 \%$ found the flipped classroom to be more engaging than the conventional classroom, while $13.3 \%$ were neutral and $6.7 \%$ disagreed. When it came to the issue of learning materials, $83.3 \%$ reported that they strongly agreed that the flipped classroom provided materials to support their learning. In addition, the results from the questionnaire revealed that the majority of students were: (1) satisfied with their experience of a flipped classroom (93.4\%) and (2) highly satisfied with the format and structure of the learning materials presented on Edmodo as an online learning environment $(96.6 \%)$. Overall, when asked about their preferences, the majority of students reported that they would prefer to register in flipped classroom. This therefore suggests a positive experience $(96.7 \%)$.

The findings from the students' semi-structure interviews also demonstrate similar results. Some students declared that the flipped classroom was beneficial, and they preferred this method of teaching to the conventional classroom as it helped them to write easily:

"The flipped classroom is very useful and it helped me to easily understand what the teacher was explaining. I would absolutely take another class that has flipped materials." (Reem)

"It's so helpful. I like it because I can anticipate what we gonna learn, and make the lesson easier to learn and understand. (Halah)

"The flipped classroom allows me time to think and take the subject seriously. I found it better than the conventional class. Ahmm, in the conventional classroom I sometimes do not know what we will take, so feel like unsure about the content and whether I will find it easy or not." (Amal)

\subsection{Flexibility of Time}

As a result of experiencing writing as a tedious task, requiring both time and effort, the majority of students (53.3\%) strongly agreed and $43.3 \%$ agreed that the flipped classroom strategy allowed them enough time to practice their writing skills both inside and outside the classroom. $86.7 \%$ strongly agreed that they found it more convenient to study at home. When asked about the effort they made in the flipped classroom in comparison with that of the conventional classroom, $56.7 \%$ of the students strongly agreed and $23.3 \%$ agreed that they made more effort in the flipped classroom. Furthermore, most of the students $(83.3 \%)$ strongly agreed that they were eager to watch the videos and other materials prior to their class. The interviews with the students therefore confirm 
that the flipped classroom provides learners with flexible learning time.

"The thing I like most in the flipped classroom is that I can watch the video whenever I want." (Hala)

"The best thing about the flipped classroom is that I can watch the video many times at any time of the day, using my smartphone." (Nora)

"I felt that I could ask the teacher or my classmates any question at any time, which really helped me to become very engaged in the class and improve my writing. With the flipped classroom, I do not have to wait until the lesson to ask questions." (Manal)

\subsection{Interaction and Participation}

The students' responses also indicated that the flipped classroom improved participation and interaction (Q11, Q12 and 13 ). 50\% of the students strongly agreed and 36.7\% agreed that they felt they had more opportunities to participate in writing activities in a flipped classroom. Furthermore, $70 \%$ of the students believed the flipped classroom allowed them to engage in peer interaction, with $13.3 \%$ disagreeing and a similar percentage remaining neutral. The interviews with the students revealed that advance preparation led to a more enjoyable experience of classroom activities and better interaction. For example, Sarah and Hessah reported that:

"I started to love contributing to my classroom activities, because I knew what to say and how to do them. In my previous class, I mean you know the basic writing classroom when the teacher asked us to write something, I felt that I was not prepared, or sometimes I had the feeling that I would do things wrongly. However, in this class I had the chance to see illustrative videos and so felt confident about contributing to the activities." (Sarah)

"Writing is not easy but with the flipped classroom I felt I can say something because vidoes were inspiring it shows me how to write step by step how to do things not perfectly but at least right (...) yeah also when you ask me to write something without preparing it not easy at all (...) honestly I enjoyed the classroom activities because I came to the class with prepared mind"(Hessah)

\subsection{Improvement in Writing Skills}

The students' responses to questions Q2, Q3, Q4, Q5 and Q9 highlighted the potential of the flipped classroom to support their writing skills. The majority (93.4\%) strongly agreed that the flipped classroom improved their writing skills, along with their planning strategies (86.7\%). In addition, $63.9 \%$ strongly agreed that it improved their ability to write a correct thesis statement and topic sentences, with $33.3 \%$ remaining neutral. Furthermore, $50 \%$ of students observed an improvement in their use of grammar in written work as a result of the flipped classroom, while $16.7 \%$ did not and $30 \%$ were neutral. Moreover, $66 \%$ of the students felt that being given immediate feedback on Edmodo improved their writing. Thus, the interviews with students corroborated the findings of the questionnaire, i.e. that the videos and online exercises helped to improve their writing.

"The flipped classroom is the best way to understand and learn in this subject. I understand many lessons in this way, also my writing skills improved by watching videos and practicing at home." (Hessah).

"The easiest way to learn is through the flipped classroom. I've learned how to write a good essay and all of that's because of what we were given before the class. I think I can write better now." (Nora)

"For me, I felt that my writing has improved a lot. I started to think carefully about the unity and coherence of my paragraphs as a result of seeing one of the videos, which provided really good illustrative examples, and I had more chance to think about this in class while you (she is referring to the teacher) was explaining this in class." (Nada)

The responses to the questionnaire items demonstrate the students' highly positive attitude toward the strategy of the flipped classroom. As detailed previously, the highest positive responses indicated students' belief that the flipped classroom improved the learning environment and their motivation when it came to writing. However, their responses varied in relation to the usefulness of this strategy for improving their use of form (i.e. grammar) and content (i.e. writing a correct thesis proposal and using topic sentences). The interview data may also further shed further light on a number of issues appearing to limit the usefulness of this strategy, i.e. how students perceived learning. This aspect is discussed in further detail in the following section.

\subsection{Issues Related to the Flipped Classroom}

Despite the positive findings from the questionnaire, there remain a number of contextual issues related to the students' perception of the flipped classroom strategy. Some retained a preference for the teacher giving instruction from the front of the class. 
"Yes, the flipped classroom is enjoyable. However, I prefer to understand the materials directly from the teacher, not the videos, because whenever I get confused or uncertain I can ask the teacher." (Gazlan)

"I do not think that videos and online activities can replace my teacher's role. I still prefer to learn from my teacher. I have chosen to be in her class and prefer her way of teaching one to one. She talks and we listen and take notes". (Mona)

The students appeared to experience uncertainty when watching a video and sometimes asked for instructions to be repeated.

"Even though I was watching each video the teacher posted, I always raised my hand and asked the teacher to repeat what was given in the videos, just to make sure that I understood it correctly, especially when it comes to grammar". (Isra)

In addition, a number of other students remained unconvinced that their peers could be a reliable source of information. Anfal reported that

"I enjoyed the flipped classroom, but I did not like the fact that we came to the class and have a group discussion. I do not trust my classmates and I felt that sometimes they correct my writing wrongly." (Anfal)

"Their levels of English (referring to classmates) is not that good, especially when the teacher asked us to sit with low achieving students. I still prefer to receive feedback from my teacher, as she has more knowledge than my classmates". (Salma)

"One of the students was rude. She crossed out all my paragraphs and told me that my work was not good. I felt sad, and at the same time angry, because she did not have the right to say that something was right or wrong. She was not our teacher." (Amal)

Further issues highlighted in the data from the interviews related to examinations. The students stated that, although they enjoyed the flipped classroom, they still wanted to be given more information about the examination questions. Rawan, for example, stated feeling anxious:

"Although I was enjoying the activities and the group work, I was thinking a lot about the exam. How I am going to do this individually? When we are working in a group we help each other, but in an exam we are supposed to do this by ourselves without help." (Rawan)

This was reiterated by Noha:

"My only issue was that of the examination. I was worried about the exam's questions and whether the teacher would allow us to use other supportive materials, such as an electronic dictionary. I asked the teacher whether these activities are included in the exam and do we have to study all of them, which was a little bit embarrassing." (Noha)

The interviews with the students also suggested that they valued information posted by the teacher and seem to be relying on her for finding suitable online materials.

"You know YouTube is full of educational videos, however, I felt that it is better when our teacher recommended something I felt it much more illustrative and related to our lesson." (Seham)

"Our teacher knows how to choose the suitable and most useful videos for us... I used to search for educational videos on other subjects and it is not easy to find one that match what you are looking for." (Marwa)

\section{Discussion}

This study explored the perceptions of Kuwaiti EFL student teachers of the application of the flipped classroom instructional strategy in their advanced writing classroom. The most significant results of the study were firstly, that the students held an overall positive attitude towards the flipped classroom, and secondly, that the main pedagogical benefits of flipping the writing classroom consisted of: (1) providing a more conducive learning environment; (2) improving students' classroom interaction; (3) increasing learners' motivation towards writing; (4) providing flexible paced learning; and (5) improving writing skills. These findings are in line with a number of other studies reporting positive attitudes towards the flipped classroom (Abdulla et al., 2019; Amiryousefi, 2017; Bergman \& Sams, 2013; Doman \& Webb, 2017; Haghighi, et al., 2018; Huynh \& Nguyen, 2019). Furthermore, the findings of the current study also concur with those of Ekmekci (2017) and Abdulla et al. (2019), who found that the flipped classroom can improve the written skills of EFL learners.

A further significant finding of the current study confirms the alignment between sociocultural theory and the principle of the flipped classroom. Thus, the interview data identified that prior preparation improved students' interaction and participation in class. The implementation of the flipped classroom provides opportunities for 
collaborative learning in relation to written work, with students learning from each other (Storch, 2013). In the current study, the majority of the classroom interaction was devoted to working in groups, with an emphasis on peer-to-peer learning. Furthermore, this study confirms that the flipped classroom not only increases learners' in-class interaction, but also provides a more flexible learning environment (Ekmekci, 2017). Similar to the findings of previous studies (Amiryousefi, 2017; Doman and Webb, 2017; Hung, 2015; Yang et al., 2018), the majority of students in this current study reported finding the flipped classroom more engaging than the conventional classroom. This does not imply that the traditional writing classroom is ineffective, but rather highlights the importance of the flipped classroom in promoting learners' motivation towards their written work. The descriptive statistical analysis indicates that learners' positive responses were mainly recorded in relation to motivation, with students experiencing enhanced motivation towards writing when applying the flipped classroom. Therefore, in line with Haghighi et al. (2018), the innovative procedure employed in the flipped classroom may have motivated students to spend additional time and effort to engage with their writing classroom, thus improving their writing skills.

Despite these positive findings, a number of sociocultural issues were identified that appeared to impact on learners' interaction in flipped classroom. These related to: (1) learners' doubts concerning the effectiveness of peer feedback; (2) uncertainty relating to the explanations given in the videos; and (3) concerns about examinations and assessment. These findings also concurred with previous studies. For example, Homma (2015) argued that learners can resist sudden change during the application of the flipped classroom. Learners also questioned the quality of the presentation style of their peers and the usefulness of the videos' content (Engin, 2014). The current study found that the participants were familiar with solitary writing, with individual assessment and grades prioritized over group work. Similar to Webb et al.'s (2014) study of EFL Chinese students, the Kuwaiti students in this study retained a preference for instruction given by their class teacher, believing he/she to be the most reliable source of knowledge. Furthermore, as reported by Engin (2014), the students in the current study were also concerned about the quality of the videos.

\section{Conclusion}

This study has confirmed the pedagogical benefits of the flipped classroom in the EFL context, with the findings having a number of pedagogical implications. Firstly, that the flipped classroom is an effective strategy for EFL written work. The incorporation of the flipped classroom into the writing classroom appeared to enhance motivation and provide an improved learning environment, with a subsequently positive impact on the writing performance of students. Secondly, the flipped classroom provides ample opportunities during written tasks for EFL learners to interact and use language in an effective collaboration, in order to co-construct knowledge (Vygotsky, 1978). Thirdly, the flipped classroom provides an improved learning environment, with the students in the current study feeling more motivated and engaged than in the conventional classroom. Finally, and most importantly, educators and teachers should be aware that some students may resist the implementation of the flipped classroom. Thus, the introduction of this strategy can create tension between current institutional culture (which places an emphasis on the teacher-fronted classroom and a focus on examinations) and the self/independent-taught and group work strategies originating in the flipped classroom. Therefore, teachers wishing to apply the flipped classroom strategy need to organize orientation sessions with their students, in order to discuss the changes required to obtain the greatest benefit from the flipped classroom.

This study has a number of limitations. Firstly, due to the segregated nature of classes in the college, all the participants were female. Secondly, the study was conducted in the researcher's own class, which has the potential to impact on the students' responses towards the intervention. The absence of such bias could be addressed by a replication of the study with other participants and teachers. Thirdly, this study explored the effectiveness of the flipped classroom in improving writing skills by focusing primarily on students' perception and experience, without quantitative measurement of any improvement in their writing skills, including the use of a pre-post-test. This indicates the need for future studies to use a larger sample size, one that includes both genders, in order to confirm the positive influence of the flipped classroom on students' writing skills. In addition, future research could also conduct a comparative study exploring the differences between students' performance and attitudes towards writing skills in both the conventional and flipped classroom.

\section{Acknowledgement}

The author would like to thank the students who participated in this study. The anonymous reviewers whose feedback helped to considerably strengthen the paper. 


\section{References}

Abdullah, M.Y., Hussin, S. \& Ismail, K. (2019). Investigating the effects of the flipped classroom model on Omani EFL learners' motivation level in English speaking performance. Educ Inf Technol, 24, 2975-2995 (2019). https://doi.org/10.1007/s10639-019-09911-5

Adnan, M. (2017). Perceptions of senior-year ELT students for flipped classroom: a materials development course. Computer Assisted Language Learning, $204-222$. https://doi.org/10.1080/09588221.2017.1301958.

Al-Harbi, S.S. \& Alshumaimeri, Y.A. (2016). The flipped classroom impact in grammar class on EFL Saudi secondary school students' performances \& attitudes. English Language Teaching, 9(10), 60-80. https://doi.org/10.5539/elt.v9n10p60

Amiryousefi, M. (2017). The incorporation of flipped learning into conventional classes to enhance EFL learners' L2 speaking, L2 listening, \& engagement. Innovation in Language Learning \& Teaching, 1-15. https://doi.org/10.1080/17501229.2017.1394307

Bergman, J. \& Sams, A. (2012). Flip your classroom: Research every student in every class every day, USA: Iste: ASCD.

Bergman, J. \& Sams, A. (2013). Flip your students' learning. Educational Leadership, 70(6), 16-20.

Butts, A. (2014). Student views on the use of a flipped classroom approach: Evidence from Australia. Business Education \& Accreditation, 6(1) 33-43.

Cobb, L. \& Steele, C. (2014). Exploiting the fringe: flipping, microcredentials, \& MOOCs. Carrboro, NC: Tagoras.

Doman, E. \& Webb, M. (2014). The flipped \& non-flipped EFL classroom: initial reactions from Chinese university students. ThaiTESOL Journal, 27(1), 13-43.

Doman, E. \& Webb, M. (2017). The flipped experience for Chinese university students studying English as a foreign language. TESOL Journal, 8(1), 102-141

Ekmekci, E. (2017). The flipped writing classroom in Turkish EFL context: A comparative study on a new model. Turkish Online Journal of Distance Education, 18(2), 151-167

Engin, M. (2014). Extending the flipped classroom model: developing second language writing skills through student-created digital videos. Journal of the Scholarship of Teaching \& Learning, 14(5), 12-26. https://doi.org/10.14434/josotlv14i5.12829

Flipped Learning Network. (2014). The four pillars of F-L-I-P. Retrieved from http://flippedlearning.org/definition-of-flipped-learning/

Haghighi, H., Jafarigohar, M., Khoshsima, H \& Vahdany, F. (2018). Impact of flipped classroom on EFL learners' appropriate use of refusal: achievement, participation, perception. Computer Assisted Language Learning, 32(3), 261-293. https://doi.org/10.1080/09588221.2018.1504083

Hao, Y. (2016). Exploring undergraduates' perspectives \& flipped learning readiness in their flipped classrooms. Computers in Human behaviour, 59, 82-92. https://doi.org/10.1016/j.chb.2016.01.032

Homma, J.E.B. (2015). Learner autonomy \& practice in a flipped EFL classroom: Perception \& perspectives in new digital environments. Chiba University of Commerce Review, 52(2), 253-275.

Hung, H.T. (2015). Flipping the classroom for English language learners to foster active learning. Computer Assisted Language Learning, 28(1), 81-96. https://doi.org/10.1080/09588221.2014.967701

Huynh, T. \& Nguyen, U. (2019). Students' Perceptions \& Design Considerations of Flipped Interpreting Classroom. Theory \& Practice in Language Studies, 9(9), 1100-1110. https://doi.org/10.17507/tpls.0909.05

Kang, N. (2015). The comparison between regular \& flipped classrooms for EFL Korean adult learners. Multimedia-Assisted Language Learning, 18, 41-72. https://doi.org/10.15702/mall.2015.18.3.41

Kim, D. (2017). Flipped interpreting classroom flipping approaches student perceptions.pdf. The Interpreter $\&$ Translator Kim, D. (2017). Flipped interpreting classroom flipping approaches student perceptions.pdf. The Interpreter $\quad \& \quad$ Translator $\quad$ Trainer, $11(1), \quad 38-55$. https://doi.org/https://doi.org/10.1080/1750399X.2016.1198180.

Lantolf, J. (2000a). Introducing sociocultural theory. In J. Lantolf(Ed.), Sociocultural theory \& second language learning (1-26). Oxford, UK: Oxford University Press. 
Lantolf, J. (2000b). Second language learning as a mediated process. Language Teaching, 33(02), 79-96. https://doi.org/10.1017/S0261444800015329

Lantolf, J. P. (2011). The sociocultural approach to second language acquisition: Sociocultural theory, second language acquisition, \& artificial L2 development. In Alternative approaches to second language acquisition (36-59). Abingdon: Routledge.

Lantolf, J. \& Thorne, S. (2006). Sociocultural theory \& the genesis of second language development. Oxford, UK: Oxford University Press.

Mercer, N. (1996). The quality of talk in children's collaborative activity in the classroom. Learning \& Instruction, 6(4), 359-377. https://doi.org/10.1016/S0959-4752(96)00021-7

Nguyen, H.A.V., Tan, C.K. \& Lee, K.W. (2018). Students' Perceived Challenges of Attending a Flipped EFL Classroom in Vietnam. Theory \& Practice in Language Studies, 8(11), 1504. https://doi.org/10.17507/tpls.0811.16.

Storch, N. (2013). Collaborative writing in L2 classrooms: New perspectives on language \& enducation. Bristol, UK: Multilingual Matters

Strayer, J. (2012). How learning in an inverted classroom influences cooperation, innovation, \& task orientation. Learning Environments Research, 15, 171-193. https://doi.org/10.1007/s10984-012-9108-4

Swain, M. (2000). The output hypothesis \& beyond: Mediating acquisition through collaborative dialogue. In J. Lantolf (Ed.), Sociocultural theory \& second language learning (97-114). Oxford, UK: Oxford University Press.

Turan, Z \& Akdag-Cimen, B. (2019). Flipped classroom in English language teaching: a systematic review, Computer Assisted Language Learning, https://doi.org/10.1080/09588221.2019.1584117

Vygotsky, L. (1978). Interaction between learning \& development. In M. Gauvain \& M. Cole (Eds.), Readings on the development of children (34-41). New York, NY: Scientific.

Watanabe, Y. (2014). Flipping a Japanese language classroom: Seeing its impact from a student survey \& YouTube analytics. In Proceedings of ascilite 2014 Rhetoric \& Reality: Critical perspectives on educational technology (761-765). Dunedin, New Zeal\&. Retrieved http://ascilite.org/conferences/dunedin2014/files/concisepapers/325-Watanabe.pdf

Webb, M. \& Doman, E. (2016). Does the flipped classroom lead to increased gains on learning outcomes in ESL/EFLcontexts? CATESOL Journal, 28(1), 39-67.

Webb, M., Doman, E. \& Pusey, K. (2014). Flipping a Chinese University EFL Course: What Students \& Teachers Think of the Model. The Journal of Asia TEFL, 11(4), 53-87

Wu, W.C.V., Chen Hsieh, J.S. \& Yang, J.C. (2017). Creating an online learning community in a flipped classroom to enhance EFL learners' oral proficiency. Educational Technology \& Society, 20(2), 142-157

Yang, J., Yin, C. \& Wang, W. (2018). Flipping the classroom in teaching Chinese as a foreign language. Language Teaching \& technology forum, 1(22). 16-26. 


\section{Appendix A questionnaire}

\begin{tabular}{lllll}
\hline No. Items & $\begin{array}{l}\text { Strongly } \\
\text { disagree }\end{array}$ & Disagree Neutral Agree & $\begin{array}{l}\text { Strongly } \\
\text { agree }\end{array}$ \\
\hline
\end{tabular}

1 I learned better in the flipped classroom than regular classes.

2 The flipped classroom helped me to improve my writing skills.

3 The flipped classroom helped me to improve my planning strategies in writing.

4 The flipped classroom helped me to better understand how to write correct thesis statement and topic sentences.

5 My knowledge of grammar use in writing increased as a result of the flipped classroom.

6 The flipped classroom has useful tools for supporting my learning.

7 The flipped classroom gave me more time to practice writing skills.

8 The flipped classroom makes it easier and more convenient for me to study English at home

9 I would rather be taught in a flipped classroom because I receive immediate feedback.

10 I made more effort than usual when it came to flipped classroom learning activities.

11 We have the chance to participate in the class activities more than before in the flipped classrooms.

12 The flipped classroom gave me more opportunities to interact with other students.

13 The flipped classroom is more engaging than conventional classroom instruction.

14 Overall, I am satisfied with the experience of the flipped classroom.

15 I am satisfied with the format and structure of the learning materials presented on Edmodo.

16 I plan to register in flipped classroom for other subjects in the future.

17 I was eager to watch the videos and other materials set for this course prior to the class.

18 I feel more motivated towards writing because of the flipped classroom.

19 The structure and the format of the flipped classroom motivated me to take the subject seriously.

20 The use of the flipped classroom reduces a feeling of fear and tension, because of the prior preparation. 


\section{Appendix B Tests results}

Table 1. Inner consistency: correlation between items and themes $(\mathrm{n}=30)$

\begin{tabular}{ccccccccccc}
\hline \multicolumn{2}{c}{$\begin{array}{c}\text { Learning } \\
\text { environment }\end{array}$} & \multicolumn{2}{c}{ Writing skills } & \multicolumn{2}{c}{ Flexible time } & Interaction & Motivation \\
\hline Item & $\begin{array}{c}\text { Correlation } \\
\text { with theme }\end{array}$ & Item & $\begin{array}{c}\text { Correlation } \\
\text { with theme }\end{array}$ & Item & $\begin{array}{c}\text { Correlation } \\
\text { with theme }\end{array}$ & Item & $\begin{array}{c}\text { Correlation } \\
\text { with theme }\end{array}$ & Item & $\begin{array}{c}\text { Correlation } \\
\text { with theme }\end{array}$ \\
1 & $.548^{* *}$ & 2 & $.603^{* *}$ & 7 & $.702^{* *}$ & 11 & $.633^{* *}$ & 18 & $.602^{* *}$ \\
13 & $.548^{* *}$ & 3 & $.602^{* *}$ & 8 & $.683^{* *}$ & 12 & $.897^{* *}$ & 19 & $.484^{* *}$ \\
14 & $.612^{* *}$ & 4 & $.809^{* *}$ & 10 & $.477^{* *}$ & 13 & $.614^{* *}$ & 20 & $.758^{* *}$ \\
15 & $.344^{*}$ & 5 & $.681^{* *}$ & 17 & $.788^{* *}$ & & & & \\
16 & $.714^{* *}$ & 9 & $.763^{* *}$ & & & & & & \\
\hline
\end{tabular}

**. Correlation is significant at the 0.01 level

Table 2. reliability coefficients $(\mathrm{n}=30)$

\begin{tabular}{ccc}
\hline Themes & Nofitems & Cronbach's Alpha \\
\hline Learning environment & 5 & .400 \\
Writing skills & 5 & .743 \\
Flexible time & 4 & .573 \\
Interaction & 3 & .546 \\
Motivation & 3 & .700 \\
Total questionnaire & 20 & .896 \\
\hline
\end{tabular}

\section{Interview questions (Appendix C):}

1. What do you think of the flipped classroom in comparison with your regular classes in terms of time and effort you made?

2. Did you face any problems during this experience?

3. How do you think the flipped classroom you experienced helped you in writing?

4. Do you think the flipped classroom made a difference to your writing skills/ behaviours? if yes explain how? If not why?

5. What was your favourite part of flipped classroom?

6. How did you feel about interacting with your classmates in writing classroom when flipped classroom was implemented?

\section{Copyrights}

Copyright for this article is retained by the author(s), with first publication rights granted to the journal.

This is an open-access article distributed under the terms and conditions of the Creative Commons Attribution license (http://creativecommons.org/licenses/by/4.0/). 